\title{
Antimicrobial Resistant Coliforms in Tap Water with Low Free Residual Chlorine Levels in Two Hospitals: Case Study in Gaza, Palestine
}

\author{
Reem T. Abu Shomar ${ }^{1 *}$, Ayman Ramlawi², Renad Abu-Dan ${ }^{3}$, Abdelraouf A. Elmanama ${ }^{3}$ \\ ${ }^{1}$ Islamic University of Gaza and Al Azhar University, Palestine \\ ${ }^{2}$ Environmental Health Directorate Ministry of Health, Palestine \\ ${ }^{3}$ Islamic University of Gaza, Gaza, Palestine \\ Email: ^reemabushomar@gmail.com
}

How to cite this paper: Abu Shomar, R.T., Ramlawi, A., Abu-Dan, R. and Elmanama, A.A. (2021) Antimicrobial Resistant Coliforms in Tap Water with Low Free Residual Chlorine Levels in Two Hospitals: Case Study in Gaza, Palestine. Journal of Water Resource and Protection, 13, 767-777. https://doi.org/10.4236/jwarp.2021.1310040

Received: September 5, 2021

Accepted: October 11, 2021

Published: October 14, 2021

Copyright $(0) 2021$ by author(s) and Scientific Research Publishing Inc. This work is licensed under the Creative Commons Attribution International License (CC BY 4.0).

http://creativecommons.org/licenses/by/4.0/

\section{(c) (i) Open Access}

\begin{abstract}
Universal access to safe water, whether at households or health centres, is central to achieving the sixth sustainable development goal by 2030. A hospital-based survey was conducted to screen for antimicrobial resistance among coliforms in samples collected from tap water $(n=54)$ at surgical wards in Gaza and to investigate the association with free residual chlorine and $\mathrm{pH}$ levels. Total coliforms (TC) were detected in 48.1\% (26/54) of tested samples and FCs were detected in $25.9 \%$ (14/54). Free residual chlorine test ranged from zero to $0.2 \mathrm{mg} / \mathrm{l}$ (average: $0.08 \mathrm{mg} / \mathrm{l}$ ), of which more than half of the samples (53.7\%) 29/54 showed no free residual chlorine. The mean value of free residual chlorine in samples tested positive for growth on m-Endo (0.03) was lower than the mean for negative samples $(0.14)$. The $\mathrm{pH}$ values were within the acceptable range (average: 7.6 ) and there was a statistically significant variation between the mean of $\mathrm{pH}$ values for samples tested positive on m-Endo (7.29) and that tested negative (7.84). Among coliform positive samples, $23.1 \%(6 / 26)$ had coliform isolates with resistance patterns. More than two-thirds of antimicrobial resistant (AMR) isolates were resistant to amikacin, ceftazidime, ceftriaxone, and imipenem. Moreover, $50 \%$ of the isolates were resistant to piperacillin-tazobactam. One-third (33.3\%) of isolates were resistant to cefoxitin, and fosfomycin, $16.7 \%$ were resistant to ciprofloxacin, and nitrofurantoin. Intermediate resistance was shown in $16.7 \%$ of the isolates to cefoxitin and ciprofloxacin. The ESBL and carbapenem resistance genes detected in isolates were TEM (66.7\%), NDM (33.3\%), OXA (25\%), blaCTXM (16.7\%), and blaCTXM-3 (16.7\%). The finding highlighted the level of contamination with AMR coliform in samples collected from tap water and pointed out the importance of managing water safety through identi-
\end{abstract}


fying the main source of contamination, in addition to maintaining proper water disinfection at healthcare facilities for the patient, staff and environmental safety.

\section{Keywords}

Antimicrobial Resistant, Total Coliform, Faecal Coliform, Free Residual Chlorine, Water

\section{Introduction}

Antimicrobials have been effective in reducing the morbidity and mortality attributed to infectious diseases. However, with the emerging resistant bacteria, the fight against infectious bacteria became a global challenge and raised the need for new antibiotics [1] [2]. Bacteria can be identified as antimicrobial resistant either by manifesting treatment failure outcomes with antibiotics or by showing resistance patterns when applying cut-off value in antibiotic susceptibility testing [3]. Many studies in Gaza reviled high rates of antimicrobial resistance in both clinical and environmental samples collected either from hospitals or from communities [4] [5] [6].

Escherichia coli was among the prevailing microorganisms isolated from clinical samples with microbial resistance to first, second and third generation antibiotics [5] [7] [8] [9]. In Gaza, Gram-negative carbapenem resistance bacteria were detected in about $12 \%$ of clinical and environmental samples $(14.4 \%$ in Klebsiella spp. and $9.8 \%$ in E. coli) [10]. High percentage (96.6\%) of multi-drug resistance (MDR) patterns among isolated Enterobacteriaceae in Gaza seawater with an overall MDR percentage of $85 \%$ was documented [4]. However, more information about the level of contamination with resistant coliforms in water supplies needs to be available for effective infection control and prevention that can be caused by anti-microbial resistant (AMR) bacteria.

Access to safe water is a basic human right and central to achieve the sixth sustainable development goal by 2030 [11]. In Gaza, the southern governorate of the Palestinian Territories, the majority of the population (89\%) has no access to safe water through public networks [12]. The quality of groundwater aquifer, the main water source in Gaza, is not fit for human use due to salinity or contamination with nitrate. The below standard water quality, in addition to the existing deteriorated socio-economic status and the prolonged conflict has affected all aspects of life [13] [14]. The deteriorated healthcare system has also contributed to increasing the risk of AMR bacteria spread [15].

Despite the high percentage of wastewater network coverage (80\%) in Gaza [13], large quantities of untreated sewage (about 100 million liters) are discarded into seawater [16] that can infiltrate through sand layers to the underneath groundwater. The main source of water for all activities in Gaza is the overabstracted coastal aquifer. Its quality is notoriously poor: $90 \%$ of water from mu- 
nicipal wells exceeds World Health Organization (WHO) drinking water guideline levels for nitrates and $79 \%$ for chlorides. According to Ministry of Health $(\mathrm{MoH})$ reports, microbiological contamination with Total Coliforms (TC) and Faecal Coliforms (FC) were reported in water samples collected from different water supplies all over the Gaza Strip [17].

In a water assessment study conducted by an international Non-Governmental Organization (NGO) at healthcare facilities in Gaza, the results reviled high contamination risks, in particular for water tanks. In addition, it was highlighted the lack of qualified staff needed for the operation and maintenance of the existing small-scale desalination plants used for water supply at health facilities [18]. In addition, the shortage in power supply at healthcare facilities was one of the main challenges that have affected the proper operation and maintenance of medical and non-medical equipment including water desalination units.

The disinfection process aims to inactivate microbes and to provide the residual amounts needed to prevent bacterial growth during the delivery or storage of water without causing harm to health [19]. Disinfection of public water supplies, mainly through chlorination, will eliminate water related pathogens that cause harm to public health. Though, other options are being increasingly used, such as ozonation, disinfection through chlorination is still the primary method used globally. To some extent, the pre-treatment of water using sedimentation and filtration can retain most of the harmful pollutants, however, a specific disinfection process is usually added to the water treatment process to prevent the transmission of water related diseases [20] [21]. Availability of acceptable levels of free residual chlorine, in case of disinfection by sodium hypochlorite, and the absence of coliforms are used as indicators for the efficiency of the disinfection process. The minimum amount of free residual chlorine at the point of delivery should not be lower than $0.2 \mathrm{mg} / \mathrm{l}$ at $\mathrm{pH}$ values less than 8 [22]. This study aimed at detecting antimicrobial resistant coliforms in tap water samples collected from hospitals. It also investigated the association of the level of water contamination with both free residual chlorine and $\mathrm{pH}$ values.

\section{Methodology}

The study was cross-sectional and aimed to investigate the occurrence of antimicrobial resistance of coliforms in tap water samples collected from the general surgical wards at two large governmental hospitals in Gaza. The study was conducted after obtaining the Ministry of Health $(\mathrm{MoH})$ permission to collect water samples while ensuring data confidentiality through proper coding.

Fifty-four random samples were collected from tap water at two hospitals; the European Gaza Hospital (EGH) and Al Shifa hospital. One hundred milliliters was collected from tap water in sterile conditions and poured through membrane filter (pore size: $0.45 \mathrm{um}$ ). The filter was then transferred to m-Endo Agar plate to isolate and enumerated Coliforms. A representative colony from each plate was sub-cultured in 40 glycerol/60 Brain Heart Infusion Broth (BHIB) for 
Antimicrobial Susceptibility Test (AST) \& molecular testing.

The AST results were determined using the modified Kirby-Bauer diffusion technique where antimicrobials were placed onto the surface of the inoculated plates based on the Clinical Laboratory Standards Institute guidelines CLSI, 2020. Standard Polymerase Chain Reaction (PCR) technique was used to detect various resistance genes; ESBL genes (CTX-M, TEM, SHV, OXA, KPC), and NDM-1 gene.

Screening for Extended Spectrum Beta-Lactamase (ESBL) production using Double Disk Synergy Test (DDST) standard procedure was performed. In addition, Modified Hodge Test (MHT) was implemented to screen for Carbapenem resistance.

Free residual chlorine was tested using standard Dietthyl-Paraphenylene Diamine (DPD) indicator test and the $\mathrm{pH}$ value was determined using Phenole Red colorimetric method.

The collected data was summarized, tabulated, and analyzed using Statistical Package for Social Sciences (SPSS) software. The statistical significance was tested at $\mathrm{P}$ value of 0.05 .

\section{Results}

Out of the 54 water samples collected from two hospitals in the Gaza Strip, (51.9\%) 28/54 was collected from AL-Shifa and (48.1\%) 26/54 was collected from the EGH. About 52\% of the whole sample was collected from male surgery department and $48 \%$ was collected from female surgery department.

\subsection{Growth on m-Endo}

The results of bacterial growth on m-Endo Agar were (48.1\%) 26/54 for Total Coliform (TC) and (25.9\%) 14/54 for Faecal Coliform (FC). The growth was enumerated for both TC and FC and the results are shown in Table 1. Less than $10 \mathrm{CFU} / 100 \mathrm{ml}$ was detected for TCs in about $80.8 \%$ of positive samples; and more than $100 \mathrm{CFU} / 100 \mathrm{ml}$ was detected for FC in half (50\%) of samples with positive growth on $\mathrm{m}$-Endo. Considering that, there should be zero coliform/100ml in drinking water, in accordance with the World Health Organization (WHO) guidelines and the national standards for drinking water.

\subsection{Free Residual Chlorine and pH Values}

According to the WHO guidelines, for an effective disinfection process with

Table 1. Coliform Enumeration on m-Endo Agar.

\begin{tabular}{ccccc}
\hline & \multicolumn{2}{c}{ Total Coliform } & \multicolumn{2}{c}{ Faecal Coliform } \\
\cline { 2 - 5 } Bacteria Count (CFU/100ml) & N & $\%$ & N & $\%$ \\
\hline Less or equal 10 & 21 & 80.8 & 6 & 7.1 \\
More than 100 & 5 & 19.2 & 1 & 50.0 \\
\hline
\end{tabular}


chlorine, the free residual chlorine level should not reach values below $0.2 \mathrm{mg} / \mathrm{l}$ (range: $0.2-0.8 \mathrm{mg} / \mathrm{l}$ ) at end-use. In this study, the results of free residual chlorine test ranged from zero to $0.2 \mathrm{mg} / \mathrm{L}$ with an average of $0.08 \mathrm{mg} / \mathrm{L}$ and Standard Deviation (SD) of 0.09. Worth mentioning that more than half of samples (53.7\%) 29/54 had zero value of free residual chlorine. Of the total samples, $11.1 \%(6 / 54)$ had $0.1 \mathrm{mg} / \mathrm{l}$ free residual chlorine results, and the remaining (35.2\%) 19/54 had $0.2 \mathrm{mg} / \mathrm{l}$ free residual chlorine value. As shown in Table 2, the variation in the average values of free residual chlorine between AL Shifa and the EGH hospitals was statistically significant ( $\mathrm{p}$ value $=0.000$ ).

According to the Palestinian national standards for drinking water, the $\mathrm{pH}$ value of drinking water ranges between 6.5 and 8.5. In this study, the $\mathrm{pH}$ values were within the acceptable range with a minimum value of 6.8 and maximum value of 8.2. The average $\mathrm{pH}$ value was 7.6 and the SD was 0.51 . Twenty-two percent of the tested samples (12/54) were slightly acidic (below 7) and $77.8 \%$ of samples (42/54) were slightly alkaline (above 7). As shown in Table 2, the variation in the average $\mathrm{pH}$ value between AL Shifa and the EGH hospitals was statistically significant $(\mathrm{p}$ value $=0.000)$.

As shown in Table 3, higher percentage of TC growth on m-Endo was detected in AL Shifa (40.1\%) compared to (7.4\%) in EGH hospital. Also for the FC, a higher growth percentage was found in AL Shifa (25.9\%) compared to (0.0\%) in

Table 2. Average free residual chlorine (mg/l) and $\mathrm{pH}$ per Hospital.

\begin{tabular}{|c|c|c|c|c|c|c|}
\hline \multirow{2}{*}{ Hospital Name } & \multicolumn{3}{|c|}{ Al-Shifa } & \multicolumn{3}{|c|}{ EGH } \\
\hline & $\mathrm{N}$ & Mean & Std. Deviation & $\mathrm{N}$ & Mean & Std. Deviation \\
\hline \multirow{2}{*}{$\begin{array}{l}\text { Free Residual } \\
\text { Chlorine (mg/l) }\end{array}$} & 28 & 0.0 & 0.0 & 26 & 0.2 & 0.05 \\
\hline & \multicolumn{3}{|c|}{$t=16.32$} & \multicolumn{3}{|c|}{$\mathrm{p}$ value $=0.000$} \\
\hline \multirow[t]{2}{*}{$\mathrm{pH}$ value } & 28 & 7.1 & 0.3 & 26 & 8.0 & 0.20 \\
\hline & \multicolumn{3}{|c|}{$t=12.34$} & \multicolumn{3}{|c|}{$\mathrm{p}$ value $=0.000$} \\
\hline
\end{tabular}

Table 3. Coliform growth per Hospital.

\begin{tabular}{|c|c|c|c|c|c|c|}
\hline & \multicolumn{4}{|c|}{ Hospital Name } & \multirow{2}{*}{\multicolumn{2}{|c|}{ Total }} \\
\hline & \multicolumn{2}{|c|}{ Al-Shifa } & \multicolumn{2}{|c|}{ EGH } & & \\
\hline & $\mathrm{N}$ & $\%$ & $\mathbf{N}$ & $\%$ & $\mathbf{N}$ & $\%$ \\
\hline \multicolumn{7}{|c|}{ Total Coliform } \\
\hline Positive & 22 & 40.7 & 4 & 7.4 & 26 & 48.1 \\
\hline \multirow[t]{2}{*}{ Negative } & 6 & 11.1 & 22 & 40.7 & 28 & 51.9 \\
\hline & \multicolumn{2}{|c|}{$\mathrm{OR}=20.17 \mathrm{CI}=(4.99-81.48)$} & \multicolumn{2}{|c|}{$\mathrm{X}^{2}=21.56$} & \multicolumn{2}{|c|}{$\mathrm{p}<0.001$} \\
\hline \multicolumn{7}{|c|}{ Faecal Coliform } \\
\hline Positive & 14 & 25.9 & 0.0 & 0.0 & 14 & 25.9 \\
\hline \multirow[t]{2}{*}{ Negative } & 14 & 25.9 & 26 & 48.1 & 40 & 74.1 \\
\hline & \multicolumn{2}{|c|}{$\mathrm{OR}=0.50 \ldots \mathrm{CI}=(0.35-0.72)$} & \multicolumn{2}{|c|}{$\mathrm{X}^{2}=71.55$} & \multicolumn{2}{|c|}{$\mathrm{p}<0.001$} \\
\hline
\end{tabular}


EGH. The variation in the percentage growth of both TC and FC growth on m-Endo between AL Shifa and EGH hospitals was statistically significant $(\mathrm{p}<0.001)$.

By looking at the average results of the free residual chlorine in the samples tested positive for coliform growth on m-Endo (Table 4), the average residual chlorine was lower (0.03) than samples tested negative for growth on m-Endo (0.14). This variation in the average of free residual chlorine between samples tested negative and positive on $\mathrm{m}$-Endo was statistically significant ( $\mathrm{p}$ value $=$ 0.000). The findings can support the fact that increased contamination was associated with decreased levels of free residual chlorine.

As shown in Table 4, higher $\mathrm{pH}$ values were detected in samples tested negative for growth on m-Endo (average $\mathrm{pH} 7.84$ ) compared to samples tested positive (average $\mathrm{pH}$ 7.29). The variation in the average $\mathrm{pH}$ levels between samples tested negative for growth on $\mathrm{m}$-Endo and those tested positive was statistically significant $(\mathrm{p}$ value $=0.000)$. The findings indicate that increased growth was associated with lower $\mathrm{pH}$ values.

\subsection{Extended Spectrum Beta-Lactamase (ESBL) and Modified Hodge Test (MHT)}

Out of the total water samples $(n=54), 5.6 \%(3 / 54)$ were positive for ESBL while no positive MHT was detected in any of the tested water samples.

\subsection{Antibiotic Susceptibility Testing (AST)}

Out of the 26 positive coliforms in water samples collected from the two hospitals, six had coliform isolates with resistance patterns. The antibiotic sensitivity pattern is shown in Table 5. More than two-thirds of isolates were resistant to amikacin, ceftazidime, ceftriaxone, and imipenem. Moreover, $50 \%$ of the isolated coliforms were resistant to piperacillin-tazobactam. Moreover, one-third (33.3\%) of the isolated Coliforms were resistant to cefoxitin and fosfomycin, $16.7 \%$ were resistant to ciprofloxacin and nitrofurantoin. Intermediate resistant was found in $16.7 \%$ among the isolates for cefoxitin and ciprofloxacin. No resistance was detected (100\% sensitivity) to cefepime, chloramphenicol, and levofloxacin antibiotics.

\subsection{Antibiotic Resistant Genes}

As shown in Table 6, the detected resistance genes in Coliform isolates were:

Table 4. Average Residual Chlorine (mg/l) and pH per Growth on m-Endo

\begin{tabular}{|c|c|c|c|c|c|c|}
\hline \multirow{2}{*}{$\begin{array}{l}\text { Growth on } \\
\text { m-Endo }\end{array}$} & \multicolumn{3}{|c|}{ Positive } & \multicolumn{3}{|c|}{ Negative } \\
\hline & $\mathbf{N}$ & Mean & $\begin{array}{c}\text { Std. } \\
\text { Deviation }\end{array}$ & $\mathbf{N}$ & Mean & Std. Deviation \\
\hline \multirow{2}{*}{$\begin{array}{c}\text { Free Residual } \\
\text { Chlorine }(\mathrm{mg} / \mathrm{l})\end{array}$} & 27 & 0.03 & 0.07 & 27 & 0.14 & 0.08 \\
\hline & \multicolumn{3}{|c|}{$\mathrm{t}=5.42$} & & \multicolumn{2}{|c|}{$\mathrm{p}$ value $=0.000$} \\
\hline \multirow[t]{2}{*}{$\mathrm{pH}$ value } & 27 & 7.29 & 0.42 & 27 & 7.84 & 0.45 \\
\hline & \multicolumn{3}{|c|}{$t=4.66$} & \multicolumn{3}{|c|}{$\mathrm{p}$ value $=0.000$} \\
\hline
\end{tabular}


Table 5. Resistance Pattern for Coliform isolates $(n=6)$.

\begin{tabular}{ccccccc}
\hline & \multicolumn{2}{c}{ Sensitive } & \multicolumn{2}{c}{ Intermediate } & \multicolumn{2}{c}{ Resistant } \\
\cline { 2 - 7 } & $\mathrm{N}$ & $\%$ & $\mathrm{~N}$ & $\%$ & $\mathrm{~N}$ & $\%$ \\
\hline Amikacin & 2 & 33.3 & - & - & 4 & 66.7 \\
Cefepime & 6 & 100.0 & - & - & - & - \\
Cefoxitin & 3 & 50.0 & 1 & 16.7 & 2 & 33.3 \\
Ceftazidime & 2 & 33.3 & - & - & 4 & 66.7 \\
Ceftriaxone & 2 & 33.3 & - & - & 4 & 66.7 \\
Chloramphenicol & 6 & 100.0 & - & - & - & - \\
Ciprofloxacin & 4 & 66.7 & 1 & 16.7 & 1 & 16.7 \\
Fosfomycin & 4 & 66.7 & - & - & 2 & 33.3 \\
Gentamicin & 5 & 83.3 & - & - & 1 & 16.7 \\
Imipenem & 2 & 33.3 & - & - & 4 & 66.7 \\
Levofloxacin & 6 & 100.0 & - & - & - & - \\
Nitrofurantoin & 5 & 83.3 & - & - & 1 & 16.7 \\
Piperacillin-Tazobactum & 2 & 33.3 & 1 & 16.7 & 3 & 50.0 \\
\hline
\end{tabular}

Table 6. Antibiotic Resistance Genes among Coliform Isolates $(\mathrm{n}=6)$.

\begin{tabular}{ccccc}
\hline & \multicolumn{2}{c}{ Positive } & \multicolumn{2}{c}{ Negative } \\
\cline { 2 - 5 } & $\mathbf{N}$ & $\%$ & $\mathbf{N}$ & $\%$ \\
\hline blaCTXM & 1 & $16.7 \%$ & 5 & $83.3 \%$ \\
blaCTXM3 & 1 & $16.7 \%$ & 5 & $83.3 \%$ \\
KPC & 0 & $0.0 \%$ & 6 & $100.0 \%$ \\
NDM & 2 & $33.3 \%$ & 4 & $66.7 \%$ \\
OXA & 0 & $0.0 \%$ & 6 & $100.0 \%$ \\
SHVR & 0 & $0.0 \%$ & 6 & $100.0 \%$ \\
TEM & 4 & $66.7 \%$ & 2 & $33.3 \%$ \\
\hline
\end{tabular}

TEM (66.7\%), NDM (33.3\%), OXA (25\%), blaCTXM (16.7\%), and blaCTXM-3 $(16.7 \%)$. Other screened genes that were not detected by the molecular testing are SHV, KPC, and OXA. It is worth noting that both carbapenem resistant gene (NDM), and ESBL genes were detected in Coliforms isolated under this study.

\section{Discussion}

This water survey was to inspect the presence of antimicrobial resistant coliforms in samples collected from tap water $(n=54)$ under sterile conditions at surgical wards in Al Shifa and European Gaza hospitals. The level of contamination with TC reached $48.1 \%$ while the contamination with FC was about $25.9 \%$. According to the most recent water survey conducted by the Palestinian Central Bureau of Statistics and Mercy Corps Non-Governmental Organization, higher 
rates of contamination with E. coli (36.6\%) (30.5\%) were detected in drinking water samples collected at the consumer end in the households [12] [23]. In India, higher levels of contamination were detected in eleven out of fourteen (79\%) samples collected from drinking water at governmental hospitals [24].

The low levels of free residual chlorine in water samples collected from both hospitals would increase the risk for higher microbial contamination. The significant variation in the average levels of free residual chlorine between AL Shifa $(0.00 \mathrm{mg} / \mathrm{l})$ hospital and EGH $(0.17 \mathrm{mg} / \mathrm{l})$ can explain the higher levels of coliforms in water samples collected from tap water at AL Shifa hospital. The average value of free residual chlorine in samples tested positive for growth on m-Endo (TC or FC) was 0.03 which is lower than the average in samples tested negative 0.14 ( $\mathrm{p}$ value $=0.000)$.

Though the findings show acceptable results for $\mathrm{pH}$ values in the tested samples, coliforms tend to be higher in water samples with lower $\mathrm{pH}$ values. In $\mathrm{AL}$ Shifa Hospital, the average $\mathrm{pH}$ was 7.14, which is lower than what was reported in $\mathrm{EGH}$ 8.02. The average $\mathrm{pH}$ value in samples tested positive for growth on m-Endo (TC or FC) was 7.29, which is lower than 7.83 , the average $\mathrm{pH}$ in samples tested negative $(\mathrm{p}$ value $=0.000)$.

Compared to one study conducted in the rural area in the USA where all isolated coliforms from water samples were sensitive to all used antibiotics [25], six samples out of the total twenty-six coliform isolates $(23.1 \%)$ showed resistance patterns. More than two-thirds of the AMR isolates in this survey were resistant to amikacin, ceftazidime, and ceftriaxone, and imipenem. Moreover, 50\% of the isolates were resistant to piperacillin-tazobactam. In addition, about one-third (33.3\%) of the isolates were resistant to cefoxitin and fosfomycin. $16.7 \%$ of isolates were resistant to ciprofloxacin and nitrofurantoin. Intermediate resistant was shown in $16.7 \%$ of coliform isolates to cefoxitin and ciprofloxacin.

Within the whole sample, ESBL producing Coliform was detected in 5.6\% (3/54). The ESBL genes detected in Coliform isolates under this study were: TEM (66.7\%), OXA (25\%), blaCTXM (16.7\%), blaCTXM-3 (16.7\%), SHV (0.0\%). In China, similar ESBL genes including; SHV, TEM, and blaCTXM, were detected in water samples [26].

Despite testing negative for Modified Hodge Test (MHT), imipenem resistant Coliforms were detected in $66.6 \%$ of resistant isolates $(4 / 6)$ which can be used as an indicator for the presence of Carbapenem resistance among coliforms. The NDM gene was only found in half $(2 / 4)$ of the isolates that were resistance to Imipenem. It is worth mentioning that antibiotic resistance genes can be involved in horizontal transfer of resistance genes inducing resistance trait to surrounding microorganisms that were sensitive to antibiotics before receiving the resistance genes [27].

\section{Conclusion}

The findings undine the level of water pollution with coliforms in the samples 
collected from tap water in healthcare facilities and its association with low levels of free residual chlorine in the same water source. They also highlighted that the level of antibiotic resistance among coliform isolates and the presence of ESBL and carbapenem resistance genes. The results outlined the need to prioritize interventions to maintain water safety through proper disinfection and to investigate the root cause for this contamination with AMR coliforms.

\section{Acknowledgements}

The authors would like to acknowledge the financial support provided by; Oxfam-OPTI "WASH Program" under the award funded by EU, and by the Global Health Institute at the American University of Beirut (AUB-GHI). The authors also would like to thank the Palestinian $\mathrm{MoH}$, in particular, the Engineering Department and the Environmental Health for their support during the sampling process.

\section{Conflicts of Interest}

The authors declare no conflicts of interest regarding the publication of this paper.

\section{References}

[1] Tacconelli, E., Carrara, E., Savoldi, A., Harbarth, S., Mendelson, M., Monnet, D.L., et al. (2018) Discovery, Research, and Development of New Antibiotics: The WHO Priority List of Antibiotic-Resistant Bacteria and Tuberculosis. The Lancet Infectious Diseases, 18, 318-327. https://doi.org/10.1016/S1473-3099(17)30753-3

[2] Capita, R. and Alonso-Calleja, C. (2013) Antibiotic-Resistant Bacteria: A Challenge for the Food Industry. Critical Reviews in Food Science and Nutrition, 53, 11-48. https://doi.org/10.1080/10408398.2010.519837

[3] MacGowan, A.P. (2008) Clinical Implications of Antimicrobial Resistance for Therapy. Journal of Antimicrobial Chemotherapy, 62, ii105-ii114. https://doi.org/10.1093/jac/dkn357

[4] Elmanama, A.A., Hartemann, P., Elnabris Kamal, J., Ayesh, A., Afifi, S., Fatma, E., et al. (2016) Antimicrobial Resistance of Staphylococcus aureus, fecal streptococci, Enterobacteriaceae and Pseudomonas aeruginosa Isolated from the Coastal Water of the Gaza Strip-Palestine. The International Arabic Journal of Antimicrobial Agents, 6, Article No. 2. https://doi.org/10.3823/792

[5] Al Laham, N.A. (2012) Distribution and Antimicrobial Resistance Pattern of Bacteria Isolated from Operation Theaters at Gaza Strip. Journal of Al Azhar University-Gaza (Natural Sciences), 14, 19-34.

[6] El Aila, N.A., Al Laham, N.A. and Ayesh, B.M. (2017) Nasal Carriage of Methicillin Resistant Staphylococcus aureus among Health Care Workers at Al Shifa Hospital in Gaza Strip. BMC Infectious Diseases, 17, Article No. 28. https://doi.org/10.1186/s12879-016-2139-1

[7] Tayh, G., Ben Sallem, R., Ben Yahia, H., Gharsa, H., Klibi, N., Boudabous, A., et al. (2017) First Report of Extended-Spectrum $\beta$-Lactamases among Clinical Isolates of Klebsiella pneumoniae in Gaza Strip, Palestine. Microbial Drug Resistance, 23, 169-176. https://doi.org/10.1089/mdr.2016.0089 
[8] Hujier, A. and Saleem, N. (2006) Detection of Methicillin-Resistant Staphylococcus aureus in Nosocomial Infections in Gaza Strip. Islamic University, Gaza.

[9] Elmanama, A.A., Alyazji, A.A. and Abu-Gheneima, N. (2011) Antibacterial, Antifungal and Synergistic Effect of Lawsonia inermis, Punica granatum and Hibiscus sabdariffa. Annals of Alquds Medicine, 7, 33-41.

[10] Rida, R.H., Al Laham, N.A. and Elmanama, A.A. (2018) Carbapenem Resistance among Clinical and Environmental Gram-Negative Isolates Recovered from Hospitals in Gaza Strip. Palestine. GERMS, 8, 147-154.

https://doi.org/10.18683/germs.2018.1142

[11] Hutton, G. and Varughese, M. (2016) The Costs of Meeting the 2030 Sustainable Development Goal Targets on Drinking Water, Sanitation, and Hygiene. World Bank Group, Washington, DC. https://doi.org/10.1596/K8543

[12] Palestinian Water Authority (2019) Water Safety for Public Health Status Joint Report. Gaza, Palestine.

[13] World Bank (2017) Towards Water Security for Palestinians: A Diagnostic of Improvements Needed in Water and Sanitation Services in the West Bank \& Gaza. World Bank Group, Washington, DC.

[14] Shomar, R.A., Abdelatif, M. and Kishawi, Y. (2017) Visualising the Spatial Distribution of Diarrheal Disease Using the Geographical Information System: A WASH Perspective. International Journal of Global Environmental Issues, 16, 76-90. https://doi.org/10.1504/IJGENVI.2017.083421

[15] Office for the Coordination of Humanitarian Affairs (OCHA) (2020) Two Years on: People Injured and Traumatized During the "Great March of Return" Are Still Struggling.

[16] Costal Municpalities Water Utilities (2018) Costal Municipalities Water Utilities: Annual Report 2017. Costal Municpalities Water Utilities, Palestine, Gaza.

[17] Ministry of Health (2019) Evaluation of Water Quality in Gaza Governorates. Environmental Health Department, Gaza, Palestine.

[18] UNICEF (United Nations Children's Fund) and WeWorld-GVC (2019) WASH Assessment and Surveillance System in Health Faciliteis in the Gaza Strip. UNICEF, Gaza Strip.

[19] Centers for Disease Control and Prevention (CDC) (2020) Free Chlorine Testing. https://www.cdc.gov/safewater/chlorine-residual-testing.html

[20] New South Wales (2004) Approved NSW Recovery Plan: Davidson's Plum (Davidsonia jerseyana). Department of Environment and Conservation, Sydney.

[21] Barrie, A., Swaray, A., Barrie, M. and Beah, J. (2021) Evaluating Drinking Water Treatment Methods in the Njala University and Neighboring Mokonde Communities in Southern Sierra Leone. Natural Resources, 12, 257-270. https://doi.org/10.4236/nr.2021.128019

[22] World Health Organization (2011) Guidelines for Drinking-Water Quality. Vol. 38, WHO Chronicle. 4th Edition, World Health Organization, Geneva, 104-108.

[23] Palestinian Centreal Bureau of Statistics (2021) Palestinian Multiple Indicator Cluster Survey 2019-2020, Survey Findings Report. Palestinian Centreal Bureau of Statistics, Ramallah.

[24] Kanth, M.K., Sing, S.K., Kashyap, A., Gupta, V.K., Shalini, S., Kumar, S., et al. (2017) Microbial Study of Drinking Water in the Government Hospitals of Patna District, Bihar, India. American Scientific Research Journal for Engineering, Technology, and Sciences (ASRJETS), 38, 161-167. 
https://doi.org/10.1016/j.ibiod.2017.05.024

[25] Bergeron, S., Raj, B., Nathaniel, R., Corbin, A. and LaFleur, G. (2017) Presence of Antibiotic Resistance Genes in Raw Source Water of a Drinking Water Treatment Plant in a Rural Community of USA. International Biodeterioration \& Biodegradation, 124, 3-9. https://doi.org/10.1016/j.ibiod.2017.05.024

[26] Zhang, H., Zhou, Y., Guo, S. and Chang, W. (2015) Multidrug Resistance Found in Extended-Spectrum Beta-Lactamase-Producing Enterobacteriaceae from Rural Water Reservoirs in Guantao, China. Frontiers in Microbiology, 6, Article No. 267. https://doi.org/10.3389/fmicb.2015.00267

[27] Bird, K., Boopathy, R., Nathaniel, R. and LaFleur, G. (2019) Water Pollution and Observation of Acquired Antibiotic Resistance in Bayou Lafourche, a Major Drinking Water Source in Southeast Louisiana, USA. Environmental Science and Pollution Research International, 26, 34220-34232.

https://doi.org/10.1007/s11356-018-4008-5 